\title{
Management Model of Lakes as a Tool for Planning the remediation of Suat Ŭgurlu Lake
}

\author{
Bilge Aydın Er ${ }^{1}$, Tolga Ayeri ${ }^{1}$, Fulya Aydın Temel ${ }^{2 *}$, Nurdan Gamze Turan, Yüksel Ardalı ${ }^{1}$ \\ ${ }^{l}$ Environmental Engineering Department, Engineering Faculty, Ondokuz Mayls University, 55139 Samsun, Turkey \\ ${ }^{2}$ Environmental Engineering Department, Engineering Faculty, Giresun University, 28200 Giresun, Turkey
}

A R T I C LE IN F O

Research Article

Received 02 December 2016

Accepted 31 December 2016

\section{Keywords:}

Eutrophication

Remediation

Management

Lake

Reservoir

\begin{abstract}
A B S T R A C T
Ecological processes that occur in a lake depend on the physico-chemical (abiotic) and biotic factors of the system and the interrelations between them. It can be concluded that the current nutrient loadings from both point and non-point sources are cause to increase eutrophic case over the years. This study indicate that the sustainable utilization of reservoir in combination with proper wastewater treatment plant and controlled use of pesticides has a potential to reduce the current nutrient loadings into Suat Uğurlu Lake. The estimated nutrient reductions that could be achieved from the management scenario would be enough to revert the lake from mesotrophic situation to trophic state. The reduction of nutrient loadings into Suat Ugurlu Lake could be achieved through the practice of Integrated Water Resource Management (IWRM), through good management. However, as long as pertinent issues of urban poverty, watershed management and public awareness and involvement in water related issues are not addressed, trophic in Suat Uğurlu Lake will remain a problem.
\end{abstract}

*Corresponding Author:

E-mail: fulya.temel@giresun.edu.tr

DOI: https://doi.org/10.24925/turjaf.v5i7.732-738.1118

\section{Introduction}

Ayvac1k is a region that has great promise for the future in terms of tourism considering that the necessary measures should be taken immediately. The pollutants of terrestrial origin in Suat Uğurlu Dam in the vicinity of Yeşilırmak basin are very effective. Algae bloom is a result especially in the summer months that occur in trophic events. The organic pollutants and the main nutrients that contain nitrogen and phosphorous cause algae bloom.

The nutrients in the wastewater, the development of these substances are essential nutrients for algae, is given to the environment in large quantities. As a result of this, in the water, algae and other microorganisms increase the deterioration of water quality by decreasing dissolved oxygen concentration and the degree of undesired cause (Castellvi et al., 2001; Hawkes, 1997; Kleeberg and Kozerski, 1997).

Trophic is the excessive increase of primary production in the natural processes of the lake from an immunological perspective. Plant nutrients, solar radiation and depth, water temperature, phytoplankton structure, the geometric properties of the environment in the form of water convection and dispersion are the major factors in the formation (Lenzi et al., 2005, Aydın and Sunlu, 2004; Sunlu et al., 2005).
Results; hipolimnio in oxygen-free environment, drinking is not appropriate in terms of a water source, a reduction in the number of people living in water environment, the proliferation of unwanted species, odor problems, is emerging as an environment unsuitable for recreation (Tundisi et al.,1999; Shaw and Prepas 1990).

In terms of the trophic of water environment to be addressed in the phase one of the most important steps to accurately determine the level of trophic. Basic parameters are total phosphorus and secchi disk depth that are used to determine the level of trophic (Horppila and Nurminen, 2001; Jurdi et al., 2002). First, the level of trophic status is determined by the lake water environment. Water weight should be given to the trophic level of the environment in the absence of preventive activities (Jurdi et al., 2002; Kurnaz et al., 2016; Mutlu and Aydın Uncumusaoğlu, 2016).

Ayvacık Suat Uğurlu Dam Lake studies for a year throughout the study and annual variations of these parameters with regard to various parameters in water and sediment samples were evaluated. In the present study, TN and TP parameters for Station No 2 were evaluated in March and April months. It was observed as trophic pollution prevails in the evaluation. 


\section{Materials and Methods}

In lake and point source stations, sampling and analysis were conducted at monthly intervals. Temprature, $\mathrm{pH}$, electrical conductivity (EC), dissolved oxygen concentrations (DO), biochemical oxygen demand (BOD), and chemical oxygen demand (COD) were measured in situ at four points (APHA, 2005). Water samples were collected for the determination of other quality parameters. The map of Suat Uğurlu Dam Lake is given in Figure 1. And the satellite images of station in the study area is given in Figure 2.

Station No. 1 is in Central- Market Place called Ayvacik Place and the central station is exposed to daily pollution load (Figure 3). This station town located in the heart of the region is the most densely populated place. Station No. 2 is the discharge region of wastewater treatment plant (Figure 4).

The stream bed of the lake is spilled Station No. 3. The station represents the pollution carried by rivers (Figure 5). At this point, the heavy pollution throughout the study area and the odor is seen clearly in the surface water. Station No. 4 is a shallow area away from Ayvacik central station (Figure 6). Therefore, measurements were made in the area. This station opened near the shore from where the samples were taken by boat.

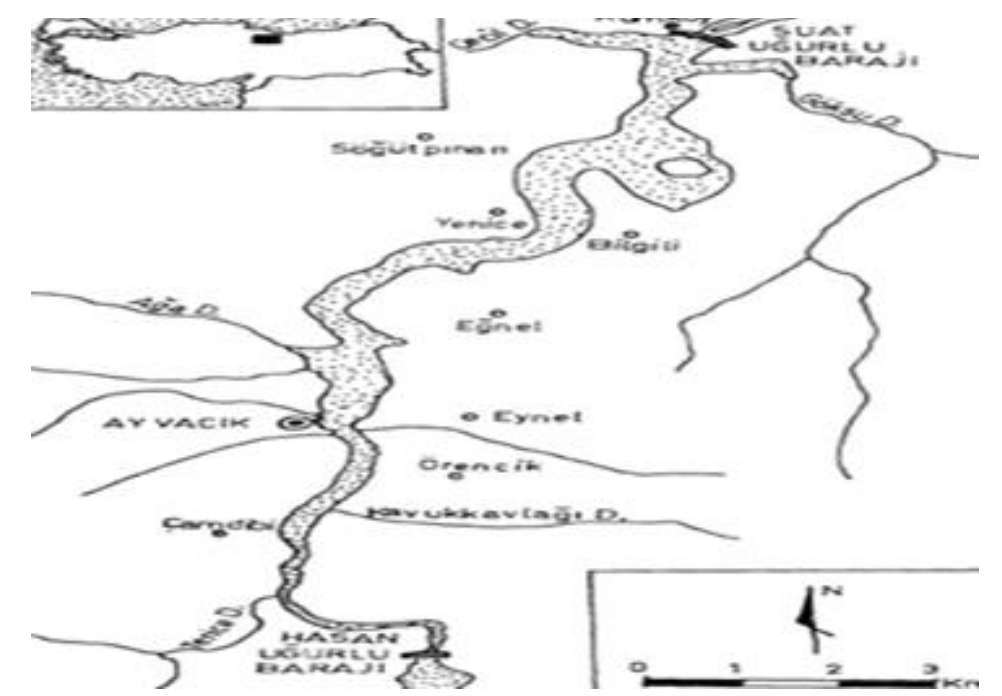

Figure 1 Suat Uğurlu Dam Lake Map (1/100000 scale topographic map)

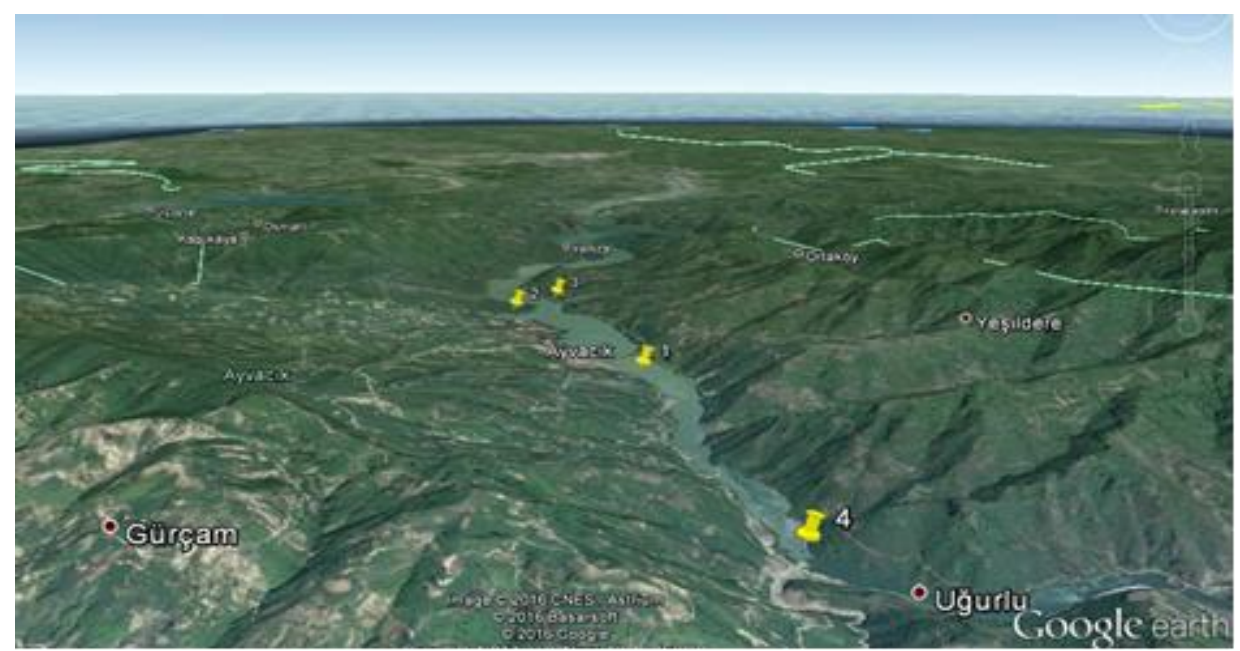

Figure 2 The satellite images of the stations identified in the study area

Table 1 Description of sampling stations

\begin{tabular}{|c|c|c|c|c|c|c|}
\hline \multirow{3}{*}{ Station } & \multirow{3}{*}{ Name } & \multicolumn{5}{|c|}{ Coordinates } \\
\hline & & \multicolumn{2}{|c|}{ ED50-6 } & \multicolumn{2}{|c|}{ ITRF-96 } & \\
\hline & & $\mathrm{X}$ & $\mathrm{Y}$ & $\mathrm{X}$ & Y & $\mathrm{Z}$ \\
\hline 1 & Center market place & 301111 & 4539931 & 553483.03 & 4539072.406 & 55.48 \\
\hline 2 & Municipal wastewater treatment plant & 300794 & 4542528 & 553077.03 & 4541656.833 & 57.08 \\
\hline 3 & Sahil village creek & 301496 & 4543051 & 553760.605 & 4542203.615 & 63.06 \\
\hline 4 & Terice stream & 300402 & 4536078 & 552906.761 & 4535197.566 & 60.62 \\
\hline
\end{tabular}




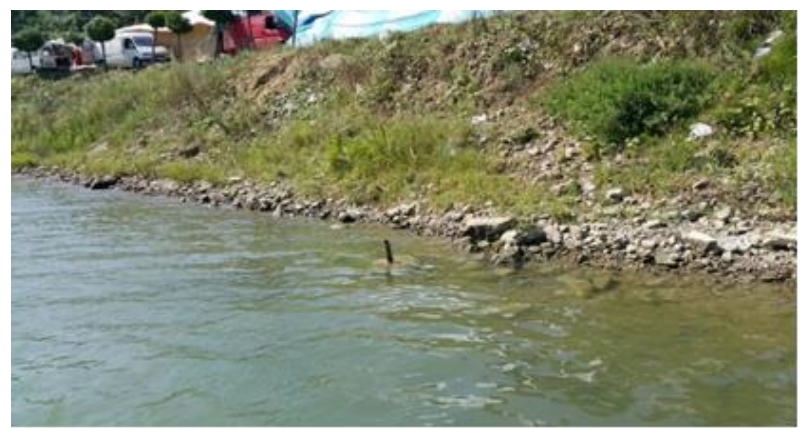

Figure 3 Station No. 1 (Central-Market Place)

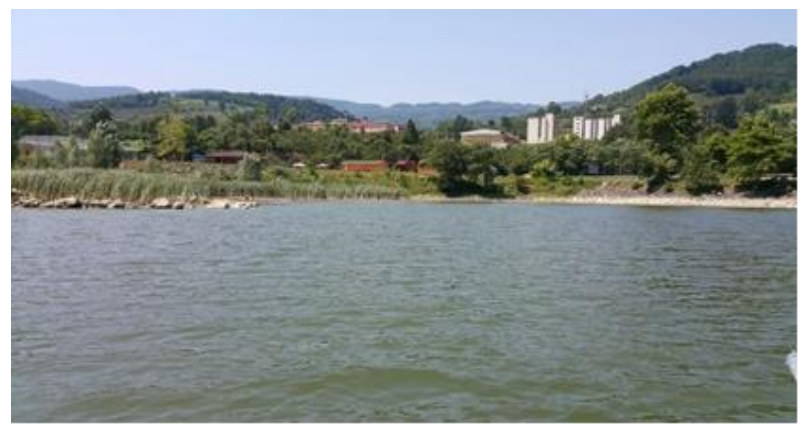

Figure 4 Station No. 2 (Wastewater Treatment Plant)

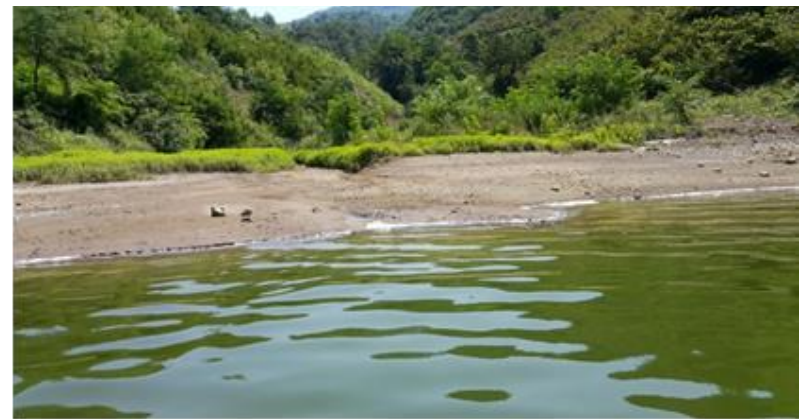

Figure 5 Station No. 3 (Sahil village-stream bed)

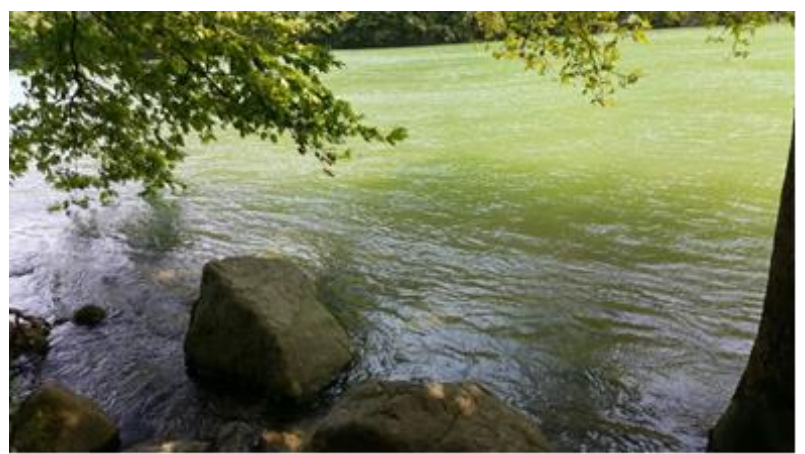

Figure 6 Station No. 4 (Terice Stream)

Table 2 Surface Water Quality Classification

\begin{tabular}{l|cccc}
\hline \multirow{2}{*}{ Parameters } & \multicolumn{4}{|c}{ Water Quality Standards } \\
\cline { 2 - 5 } & I & II & III & IV \\
\hline $\mathrm{pH}$ & $6.5-8.5$ & $6.5-8.5$ & $6.0-9.0$ & $6.0-9.0$ \\
$\mathrm{~T}$ & $\leq 25$ & $\leq 25$ & $\leq 30$ & $>30$ \\
$\mathrm{EC}$ & $<400$ & $400-1000$ & $1001-3000$ & $>3000$ \\
$\mathrm{DO}$ & $>8$ & $6-8$ & $3-6$ & $<3$ \\
$\mathrm{SD}$ & & & & \\
\hline
\end{tabular}

T: Temperature $\left({ }^{\circ} \mathrm{C}\right)$, EC: Electrical Conductivity $(\mu \mathrm{s} \mathrm{cm}-1)$,

DO: Dissolved oxygen (mg L-1), SD: Secchi Disk (m)

\section{Results and Discussion}

The trophic status of the Suat Uğurlu Dam Lake was monitored annually and measurements were performed in the field according to Surface Water Quality Control Regulation seasonal at 4 stations. The description of sampling stations in the study area is given in Table 1. The surface water quality classification is given in Table 2.

The input data used to build the model included:

- The current nitrogen and phosphorus concentrations in water $\left(\mathrm{mgL}^{-1}\right)$

- Current nitrogen and phosphorus loadings $\left(\mathrm{gm}^{-2} \mathrm{y}^{-1}\right)$

- Lake morphometry [mean depth (m), sedimentation rate $\left(\mathrm{my}^{-1}\right)$ and water residence time (years)]

Nitrogen loadings from the catchment were estimated using Eq. 1 below:

$L=Q \frac{C}{A}$

Where;

$\mathrm{L}=$ the nutrient loading $\left(\mathrm{gm}^{-2} \mathrm{y}^{-1}\right)$

$\mathrm{Q}=$ the flow rate in $\left(\mathrm{m}^{3} \mathrm{~s}^{-1}\right)$

$\mathrm{A}=$ the surface area of the lake $\left(\mathrm{m}^{2}\right)$

$\mathrm{C}=$ concentrations $\left(\mathrm{mgL}^{-1}\right)$

This model with the load $\mathrm{P}$ in the water describes the relationship between depth and hydraulic retention time.

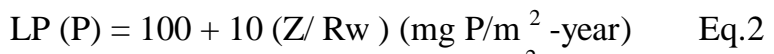

$\mathrm{Le}(\mathrm{P})=200+20(\mathrm{Z} / \mathrm{Rw})\left(\mathrm{mg} \mathrm{P} / \mathrm{m}^{2}\right.$-year $) \quad$ Eq.3

Where; $\mathrm{Z}(\mathrm{m})$ is the average depth of the lake and the RW represents the hydraulic retention time (year).

The lake volume is $182 \times 10^{6} \mathrm{~m}^{3}$, the surface area is $9.7 \mathrm{~km}^{2}$ and the average depth of lake is $18 \mathrm{~m}$.

In this case;

$\mathrm{Rw}=\mathrm{V} / \mathrm{Q}=182 \times 10^{6} \mathrm{~m}^{3} / 4.85 \times 10^{9} \times 365=1.3$ year $\mathrm{Lp}(\mathrm{P})=100+10(18 / 1.3)=238.462 \mathrm{mg} \mathrm{Pm}^{-2}$ year $^{-1}$ $\mathrm{Le}(\mathrm{P})=200+20(18 / 1.3)=476.923 \mathrm{mg} \mathrm{Pm}^{-2}$ year $^{-1}$

$\mathrm{L}(\mathrm{P})=$ Total Phosphorus Entering Lake / Lake Surface $\mathrm{L}(\mathrm{P})=248.162 \mathrm{mg} \mathrm{Pm}^{-2}$ year $^{-1}$

The results of Suat Uğurlu Lake water quality for all season in Station 2 are given in Table 3. The model outputs of Total-N in March and April are given in Figure 7, respectively.

When we consider the parameters that cause trophic, the trophic level of Suat Uğurlu Dam Lake was observed an increase with temperature rise in the spring months and decrease precipitation in the summer months. Trophic clasification is given in Table 4. This study is a short term improvement. More long-term improvement requires for a more comprehensive study. The model outputs of Tolal-P in March and April are given in Figure 8, respectively. 
Table 3 Suat Uğurlu Lake water samples in the evaluation of the fall, winter, spring and summer at Station 2

\begin{tabular}{|c|c|c|c|c|c|c|}
\hline Seasons & Water Quality Class for Months & $\mathrm{pH}$ & Temperature $\left({ }^{\circ} \mathrm{C}\right)$ & $\mathrm{EC}(\mu \mathrm{s} \mathrm{cm}-1)$ & DO & SD \\
\hline \multirow{6}{*}{ Fall } & September & 9.17 & 26.2 & 2123 & 8.86 & 1.20 \\
\hline & Water Quality Class & IV & III & III & I & \\
\hline & October & 9.05 & 21.5 & 471 & 8.71 & 1.25 \\
\hline & Water Quality Class & IV & I & II & I & \\
\hline & November & 8.02 & 16 & 557 & 9.40 & 1.10 \\
\hline & Water Quality Class & I & I & II & I & \\
\hline \multirow{6}{*}{ Winter } & December & 8.81 & 12.08 & 478 & 7.48 & 1.60 \\
\hline & Water Quality Class & III & I & II & II & \\
\hline & January & 7.82 & 8.6 & 472 & 9.03 & 1.35 \\
\hline & Water Quality Class & I & I & II & I & \\
\hline & February & 8.12 & 12 & 434 & 8.12 & 0.80 \\
\hline & Water Quality Class & I & I & II & I & \\
\hline \multirow{6}{*}{ Spring } & March & 8.12 & 12 & 434 & 8.12 & 0.90 \\
\hline & Water Quality Class & I & I & II & I & \\
\hline & April & 7.23 & 9.5 & 331 & 9.83 & --- \\
\hline & Water Quality Class & I & I & I & I & \\
\hline & May & 7.87 & 21.2 & 361 & 13.03 & --- \\
\hline & Water Quality Class & $\mathrm{I}$ & I & II & I & \\
\hline \multirow{6}{*}{ Summer } & June & 7.65 & 24.1 & 426 & 10.65 & 0.80 \\
\hline & Water Quality Class & I & I & II & I & \\
\hline & July & 8.21 & 27 & 365 & 15.09 & 0.60 \\
\hline & Water Quality Class & I & II & I & I & \\
\hline & August & 8.22 & 26.2 & 468 & 6.70 & 1.30 \\
\hline & Water Quality Class & I & II & II & II & \\
\hline
\end{tabular}

EC: Electrical Conductivity, DO: Dissolved oxygen, SD: Secchi Disk

Table 4 Trophic classification (Anonymous, 1982)

\begin{tabular}{l|cc}
\hline Trophic class & Mean TP $\left(\mu \mathrm{gL}^{-1}\right)$ & Mean secchi $(\mathrm{m})$ \\
\hline Ultra-oligotrophic & $>4.0$ & $>12.0$ \\
Oligotrophic & $<10.0$ & $>6.0$ \\
Mesotrophic & $10-35$ & $6-3$ \\
Trophic & $35-100$ & $3-1.5$ \\
Hypertrophic & $>100.0$ & $>1.5$ \\
\hline
\end{tabular}

Table 5 The water quality parameters for Suat Uğurlu Dam Lake

\begin{tabular}{|c|c|c|c|c|}
\hline Station -1 & Fall 2014 & Winter2014-2015 & Spring 2015 & Summer 2015 \\
\hline $\mathrm{DO}\left(\mathrm{mgL}^{-1}\right)$ & 10.00 & 8.50 & 9.79 & 8.57 \\
\hline Total $\mathrm{N}\left(\mathrm{mgL}^{-1}\right)$ & 1.34 & 1.27 & 2.33 & 5.32 \\
\hline Total P $\left(\mathrm{mgL}^{-1}\right)$ & 0.50 & 0.36 & 0.50 & 0.50 \\
\hline Secchi disk (m) & 1.3 & 1.4 & ND & 0.87 \\
\hline $\mathrm{BOD}_{5}\left(\mathrm{mgL}^{-1}\right)$ & 12.50 & 7.20 & 5.52 & 5.00 \\
\hline $\mathrm{COD}\left(\mathrm{mgL}^{-1}\right)$ & 58.67 & 46.90 & 24.50 & 85.30 \\
\hline Station -2 & Fall 2014 & Winter2014-2015 & Spring 2015 & Summer 2015 \\
\hline $\mathrm{DO}\left(\mathrm{mgL}^{-1}\right)$ & 8.67 & 8.21 & 10.94 & 10.81 \\
\hline Total $\mathrm{N}\left(\mathrm{mgL}^{-1}\right)$ & 0.89 & 1.20 & 2.28 & 4.95 \\
\hline Total P $\left(\mathrm{mgL}^{-1}\right)$ & 0.50 & 0.35 & 0.50 & 0.50 \\
\hline Secchi disk (m) & 1.28 & 1.25 & ND & 0.90 \\
\hline $\mathrm{BOD}_{5}\left(\mathrm{mgL}^{-1}\right)$ & 6.30 & 7.70 & 2.90 & 4.70 \\
\hline $\mathrm{COD}\left(\mathrm{mgL}^{-1}\right)$ & 32.00 & 55.50 & 64.00 & 96.00 \\
\hline Station -3 & Fall 2014 & Winter2014-2015 & Spring 2015 & Summer 2015 \\
\hline $\mathrm{DO}\left(\mathrm{mgL}^{-1}\right)$ & 10.57 & 8.91 & 11.58 & 11.83 \\
\hline Total N $\left(\mathrm{mgL}^{-1}\right)$ & 0.44 & 1.18 & 1.82 & 6.72 \\
\hline Total $\mathrm{P}\left(\mathrm{mgL}^{-1}\right)$ & 0.50 & 0.27 & 0.50 & 0.50 \\
\hline Secchi disk (m) & 1.23 & 1.3 & ND & 1.00 \\
\hline $\mathrm{BOD}_{5}\left(\mathrm{mgL}^{-1}\right)$ & 6.70 & 7.20 & 5.10 & 6.20 \\
\hline $\operatorname{COD}\left(\mathrm{mgL}^{-1}\right)$ & 42.70 & 22.40 & 33.10 & 48.00 \\
\hline Station -4 & Fall 2014 & Winter2014-2015 & Spring 2015 & Summer 2015 \\
\hline $\mathrm{DO}\left(\mathrm{mgL}^{-1}\right)$ & 8.60 & 8.42 & 9.02 & 5.49 \\
\hline Total $\mathrm{N}\left(\mathrm{mgL}^{-1}\right)$ & 0.17 & 0.71 & 2.00 & 4.55 \\
\hline Total $\mathrm{P}\left(\mathrm{mgL}^{-1}\right)$ & 0.05 & 0.26 & 0.50 & 0.50 \\
\hline Secchi disk (m) & 1.3 & ND & ND & 1.00 \\
\hline $\mathrm{BOD}_{5}\left(\mathrm{mgL}^{-1}\right)$ & 8.50 & 7.00 & 7.80 & 5.80 \\
\hline $\operatorname{COD}\left(\mathrm{mgL}^{-1}\right)$ & 74.70 & 37.30 & 42.60 & 32.00 \\
\hline
\end{tabular}



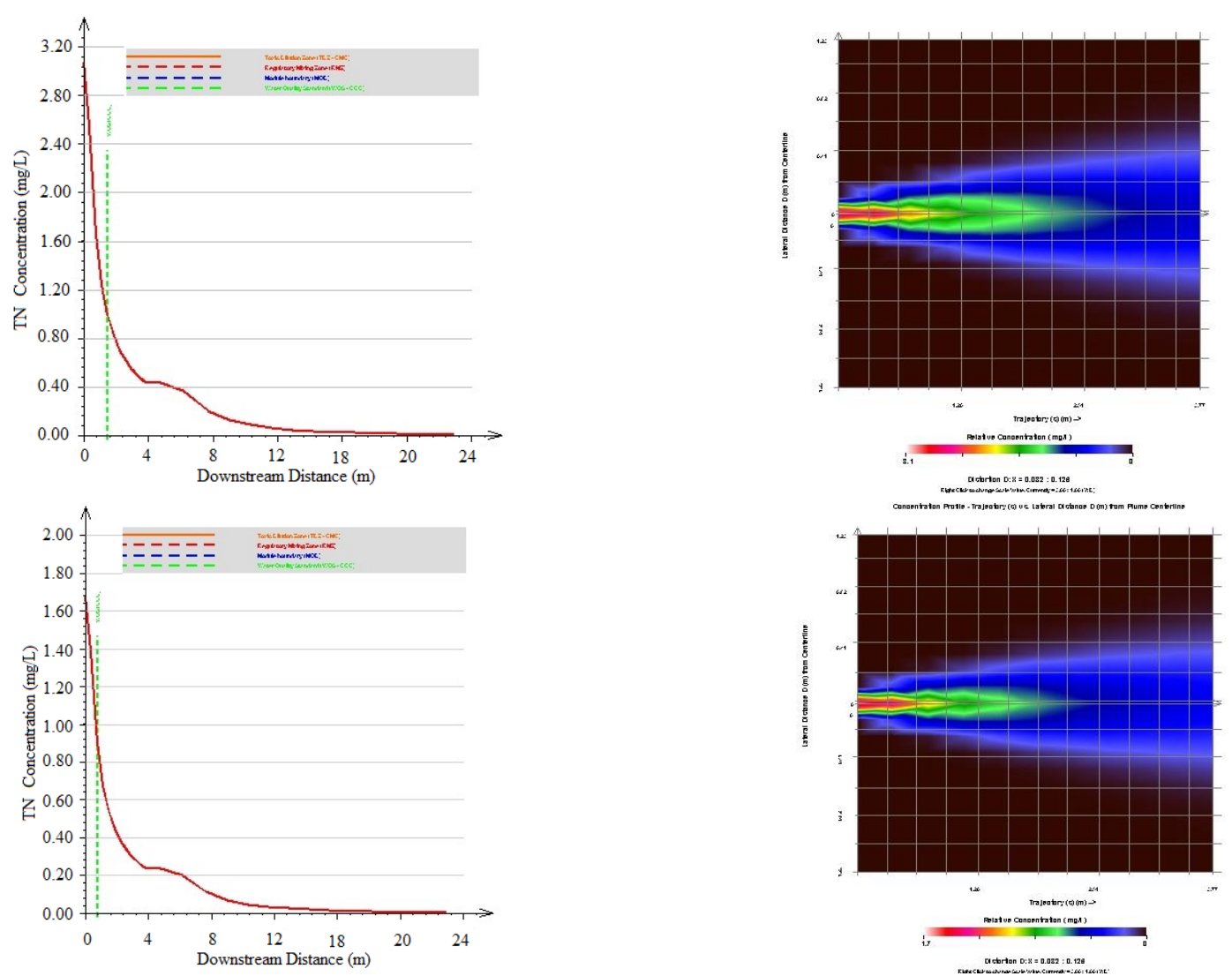

Figure 7 Total-N changes in WWT Station-2 for March (a) and April (b)
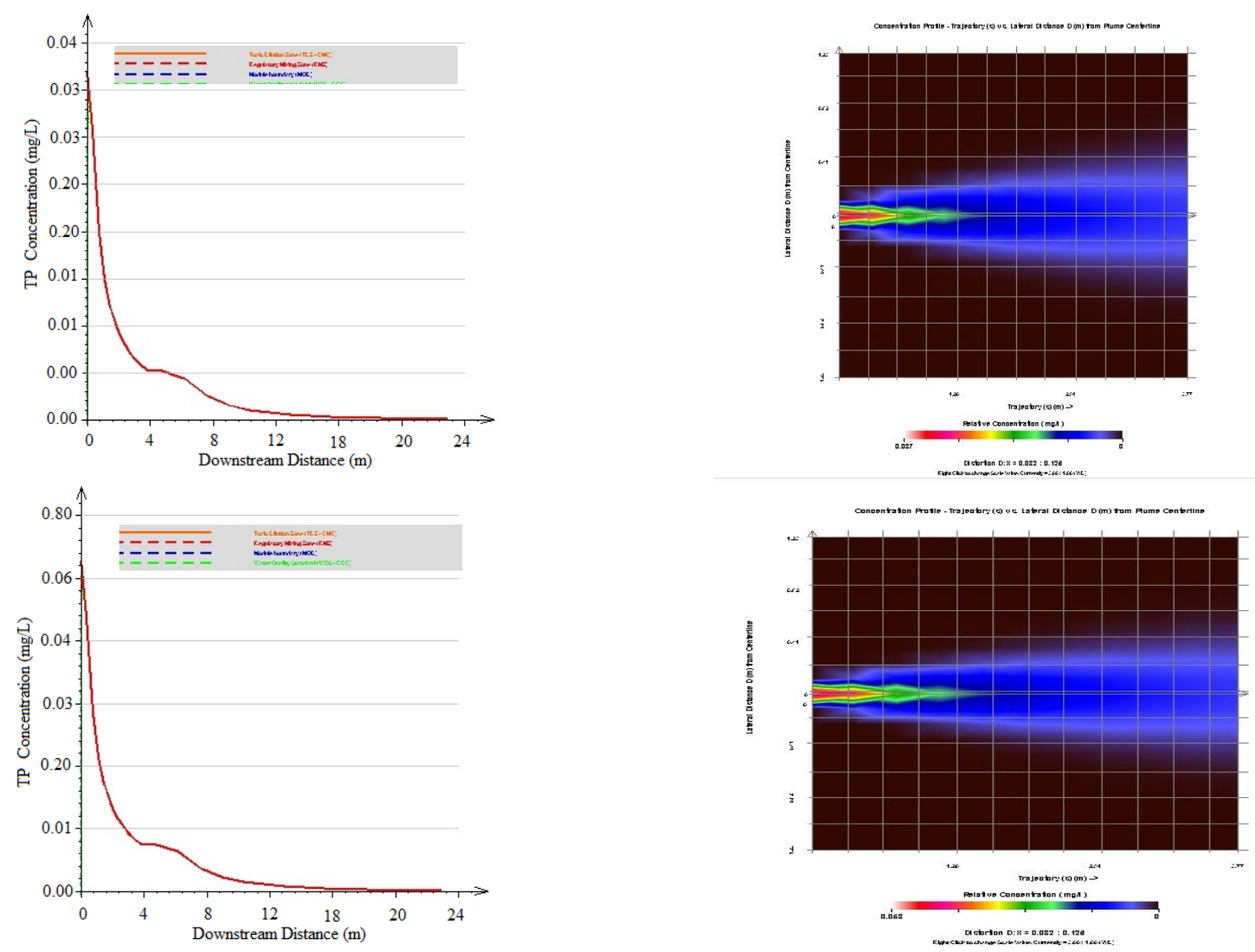

Figure 8 Total-P changes in WWT Station-2 for March (a) and April (b) 


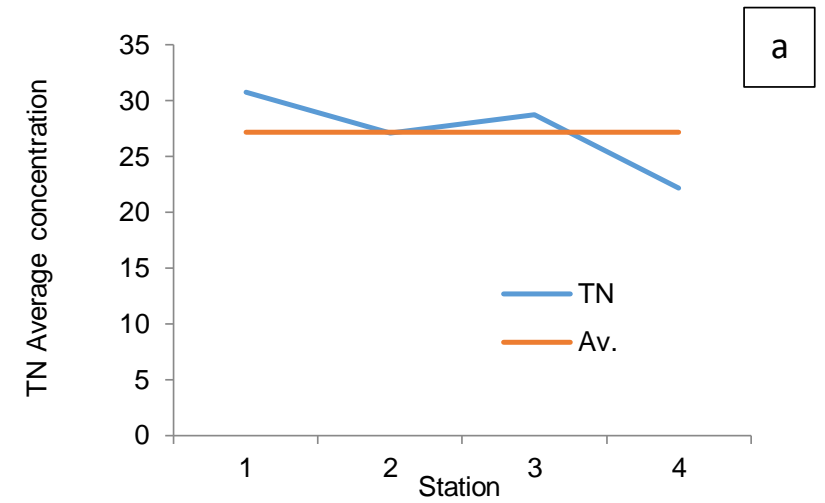

Figure 9 Average concentration of $\mathrm{TN}(\mathrm{a})$ and $\mathrm{TP}$

The data conducted in the reservoir by the effect of nutrient transported into the lake with rain water was showed that the pollution of the Yeşilırmak river basin has been transported to the lake.

Nuts throughout the perimeter of the Suat Uğurlu Dam Lake are cultivated. Nitrogenous fertilizers, animal manure and chemical fertilizers are plenty of used to increase the yield in Hazelnut cultivation. Pesticides are used extensively to protect the plant from pest in this area.

The annual average concentrations and monthly average concentrations of TN and TP for each stations are given in Figure 9, respectively.

For the elimination of trophic in the lake in the short, medium and long term regarding the work to be done our recommendations are listed follow.

- In the short term; trophic situation that may occur on the surface especially during the summer period, the algal growth by dosing alum to prevent the fragmentation of the problem may be temporarily resolved visually.

- In the medium term; photovoltaic systems at certain points of the reservoir lake water could be gained by providing ventilation with oxygen dead zones.

- In the long term can be done Yeşilırmak river basin management plan, the watershed management committee for the disposal of pollution sources within the scope of the application of the sanction is important. On the other hand, by Yeşilirmak river basin the Management Committee related to agriculture to farmers' organic farming incentive applications to be made must be provided (tax, interest-free production loans, etc.).

- Regional solutions are proposed as the aeration project in the lake as a long-term solution, but in the meantime, nutrient pollution, especially during spring active period, considering that alum dosing, shortterm can be considered as a solution. As a result, trophic pollution of Ayvacık Suat Uğurlu Dam Lake occurs as a result of vital activity and production in the region.

- Ultimately to be able to control the pollution along the River within the district boundaries precautions should be taken.

- Also, it is crucial that the people of the region to raise awareness and minimize pollution.

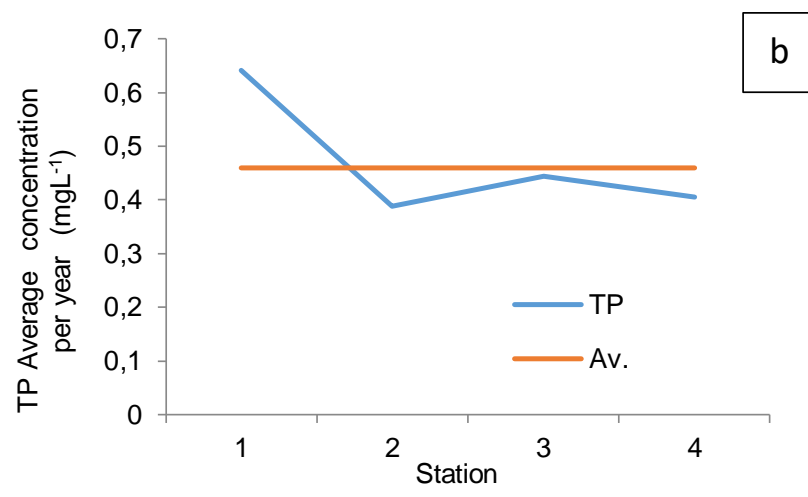

(b) per year for Suat Uğurlu Dam Lake $\left(\mathrm{mgL}^{-1}\right)$

\section{Conclusion}

This model with the trophic status index results showed that there is a transition from the mesotrophic situation to trophic situation. The water quality of the river that is located out of the lake and the lake show that it is not suitable to use as the drinking water without advanced water treatment. Lake water quality should be upgraded to class I by using appropriate chemical, biological or natural treatment proses. Ecological status is medium for Suat Uğurlu Dam Lake, the normative definition of the Water Framework Directive is trophic status or trophic may become in the near future, this lake is labeled as a sensitive area. In the Nitrate Directive, it is called that this area can be damaged from this non-point pollution.

\section{References}

APHA, AWWA, WEF. 2005. Standard Methods for The Examination of Water and Wastewater, 21st Edition, American Public Health Association, Washington, 4-103 - 4-169.

Aydın A, Sunlu U. 2004. Güney Ege Denizi sedimentinde \% karbon ve \% yanabilen madde miktarının araştırılması, E. Ü. Su Ürünleri Dergisi, 21 (3-4):229-334.

Castellvi MS, Dohet A, Vveer Borght P, Hoffmann L. 2001. Control of the eutrophic of the reservoir of Esch-sur-Sure: evaluation of the phosphorus removal by premade. Hydrobiologia, 459, 6171.

Hawkes HA. 1997. Origin and development of the biological monitoring working party score system, Wat. Res., 32 (3): 964968.

Horppila J, Nurminen L. 2001. The effect of an emergent macrophyte (Typha angustifolia) on sediment resuspension in a shallow North temperate lake. Fresh water Biology, 46: 14471455.

Jurdi M, Korfali SI, Karahogopian Y, Davies BE. 2002. Evaluation of water quality of the Qaraaoun Reservoir, Lebanon: Suitability for multipurpose usage. Environmental Monitoring and Assessment, 77 (1): 11-30.

Kleeberg A, Kozerski HP. 1997. Phosphorus release in Lake Graber Müggelsee and it simplications for lake restoration. Hydrobiologia, 342-343: 9-26.

Kurnaz A, Mutlu E, Aydın Uncumusaoğlu A. 2016. Determination of Water Quality Parameters and Heavy Metal Content in Surface Water of Çiğdem Pond (Kastamonu/Turkey). Turkish Journal of Agriculture - Food Science and Technology, 4(10): 907-913.

Lenzi M, Finoia MG, Persia E, Comandi S, Gargiula V, Solari D, Gennaro P, Porrello S. 2005. Biochemical effects of disturbance in shallow water sediment by macro algae harvesting boats. Marine Pollution Bulletin., 50: 512-519. 
Mutlu E, Aydın Uncumusaoğlu A. 2016. Physicochemical Analysis of Water Quality of Brook Kuruçay. Turkish Journal of Agriculture - Food Science and Technology, 4(11): 991-998.

Nürnberg GK, Shaw M, Dillon PJ, McQueen DJ. 1986. Internal phosphorus load on an oligotrophic precambrien shield lake with an anoxichypolimnion. Can. J. Fish. Aquat. Sci., 43: 574580 .

Shaw JFH, Prepas EE. 1990. Relationships between phosphorus in shallow sediments and in the trophogenic zone of seven Alberta Lakes. Wat. Res., 24 (5): 551-556.
Sunlu, U, Aydın, A, Özçetin NE. 2005. Kuzey Ege Denizi sedimentinde $\%$ karbon ve $\%$ yanabilen madde miktarının araștırılması, E. Ü. Su Ürünleri Dergisi, 22 (3-4): 263-268.

Tundisi JG, Matsumura-Tundisi T, Rocha O. 1999. Theoretical basis for reservoir management. Theoretical Reservoirs Ecology and its Applications, Tundisi, J.G., M. Straskrabaeds., Backhusy, 505-528. 